\title{
PREPARATION AND EVALUATION OF AVIAN PATHOGENIC E.COLI LIPOPOLYSACCHARIDE AND RIBOSOMAL VACCINES AGAINST COLIBACILLOSIS IN BROILER CHICKEN IN AL-SULAIMANIA PROVINCE

NAHLA M.S. ; SLIM S.A. ${ }^{* *}$ and YASSIN B.R. ${ }^{* *}$

"Department of Microbiology, College of Veterinary Medicine, University of Sulaimania. Suliamania, Iraq.

*** Department of Microbiology, College of Veterinary Medicine, University of Baghdad, Baghdad, Iraq.

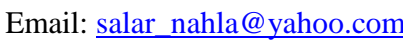

\section{ABSTRACT}

Received at:22/10/2014

Accepted: 9/12/2014
This study was conducted to evaluate the effectiveness of Lipopolysaccharide (LPS) and ribosome vaccines on $E$. coli that isolated from broiler farms in AL-Sulaimania province. Seventy five broiler chicks were used for this experiment, and they were divided into three groups. Antibodies were evaluated by using enzyme linked immune sorbent assay (ELISA) and passive hemagglutination (PHA) test at age of $17^{\text {th }}$ and $29^{\text {th }}$ day, the results showed high antibody titers in vaccinated groups in comparison with control group. The results of the ELISA at the age of $17^{\text {th }}$ day for LPS, ribosome, and control groups were the group $1.275 \pm 0.095,1.592 \pm 0.046$ and $0.046 \pm 0.009$ respectively, while at the age of $29^{\text {th }}$ day the results were $1.849 \pm$ $0.038,2.048 \pm 0.048$ and $0.985 \pm 0.010$ in LPS, ribosome and control groups respectively. The results of PHA at $17^{\text {th }}$ day were $192 \pm 24.189,272 \pm 56.406,1 \pm$ 0.7003 in LPS, ribosome and control groups respectively, while at $29^{\text {th }}$ day the results were $1344 \pm 215.003,1792 \pm 374.746$ and $256 \pm 112.813$ in LPS, ribosome and control groups respectively.

Keyword: E.coli, Lipopolysaccharide, ribosomal vaccines, avian colibacillosis

\section{INTRODUCTION}

Avian Pathogenic Escherichia coli (APEC) is the causative agent of avian colibacillosis, an illness associated with systemic infection of internal organs and a diversity of symptoms (Moulin et al., 2007).

Colibacillosis refers to any localized or systemic infection caused entirely or partly by avian pathogenic Escherichia coli (Barnes et al., 2003). It is a globally spread infectious disease that represents a main concern in the poultry industry. It is not only a welfare issue but also an economic problem because it causes respiratory problems, reduced feed intake, growth retardation, uniformity reduction, and mortality (Ask et al., 2006).

Colibacillosis, caused by avian pathogenic E. coli APEC, is also named air sac disease, chronic respiratory disease (CRD), or multi-causal respiratory disease, APEC can also cause infections in the upper respiratory tract, often referred to as the "swollen head syndrome" characterized by airsacculitis, pericarditis, peritonitis, salpingitis, polyserositis, septicaemia, synovitis, osteomyelitis and yolk sac infection (McPeake et al., 2005).
The role of E. coli in chronic respiratory diseases in broiler is well documented and its pathogenicity has been correlated with numerous extrinsic and intrinsic bird related factors and conditions. The extrinsic factors include environment, exposure to other infectious agents, virulence and level of exposure duration, active and passive immune status and breed of chicken (Gross, 1990).

Since intensive breeding has been widely applied in the poultry industry, outbreaks of acute mortality in flocks due to avian colibacillosis have frequently been observed, and are responsible for the significant economic losses (Vandekerchove et al., 2004).

Currently, the control of APEC has become not only an urgent issue but also a great challenge. Vaccination is an effective method for controlling infectious diseases (Yang, 2003). To date, a number of experimental vaccines have been developed to prevent colibacillosis (Lynne et al., 2012 and Nagano et al., 2012).

Infections caused by Escherichia coli have an economically significant impact on the poultry industry and a non-serotype-specific vaccine appears to be the most logical method of controlling them. The potential of controlling Escherichia coli 
infections in commercial poultry through vaccination has been explored widely over the past several decades. In these attempts, live or killed bacteria and their various cellular components have been used to immunize chickens (Deb and Harry, 1976; Arp, 1980 and Kariyawasam et al., 2002). Therefore, the aim of this study was to evaluate the effectiveness of ribosome and LPS vaccines on $E$. coli isolates from colibacillosis cases in broiler farms.

\section{MATERIALS and METHODS}

\section{Experimental Chicks:}

Seventy five (75) one day old broiler chicks (Breed: Ross, Belgium Origin) were brought in good condition from Al- jazera Hatchery-Amman-Jordon.

\section{Isolation and Identification of E.coli ( Vaccine Strain)}

The E.coli (vaccine strain) was isolated from the clinically affected broiler farms with colibacillosis in AL-Sulaimania Province. The isolates were culture on MacConkeys, and cosin, methylene blue (EMB) agar, and different biochemical tests were carried out for identification, the isolates were confirmed by using API E20 test and PCR technique.

\section{Detection of $E$. coli by PCR Oligonucleotide primers}

For PCR analysis of locally isolated E. coli, oligonucleotide primers targeting $16 \mathrm{~S}$ ribosomal DNA gene (Candrian et al., 1991; Amit-Romach et al., 2004), ECO-f and ECO-r were used (Table 1).

Table1: Primers were used for the detection of the E. coli.

\begin{tabular}{ccc}
\hline Primer & Primer sequence (5_-3_) & Amplification products (bp) \\
\hline ECO-f & GACCTCGGTTTAGTTCACAGA & 585 \\
\hline ECO-r & CACACGCTGACGCTGACCA & \\
\hline
\end{tabular}

\section{DNA extraction of $E$. coli}

DNA was extracted from $E$. coli isolate using DNeasy Blood and Tissue Kit (Qigen, Germany).

\section{DNA amplification}

For PCR amplification, $5 \mu \mathrm{l}$ of DNA extract was added to $45 \mu \mathrm{l}$ of PCR mixture containing $27.5 \mu \mathrm{L}$ of nuclease-free water, $5 \mu \mathrm{L}$ of each primer, $1.5 \mu \mathrm{L}$ of nucleotide (dNTP) mix, $5 \mu \mathrm{L}$ of PCR buffer, and 1 $\mu \mathrm{L}$ of Taq polymerase. The amplification conditions were: 1 cycle of $94^{\circ} \mathrm{C}$ for $3 \mathrm{~min}$ ، 35 cycles of $94^{\circ} \mathrm{C}$ for $30 \mathrm{~s}, 60^{\circ} \mathrm{C}$ for 1 minutes and $68^{\circ} \mathrm{C}$ for 2 minutes, with a final extension at $68^{\circ} \mathrm{C}$ for 7 minutes and hold for $4{ }^{\circ} \mathrm{C}$. Amplified products were separated by electrophoreses on $1 \%$ agarose gel containing ethidium bromide. The agarose gel was prepared using $1 \mathrm{gm}$ agarose powder, $100 \mathrm{ml} 1 \mathrm{X}$ Tris acitate EDTA (TAE) buffer and $5 \mu \mathrm{l}$ ethidium bromide. Agarose gel electrophoresis was conducted in $1 \mathrm{X}$ TAE buffer at $100 \mathrm{~V}$ for 35 minutes. $100 \mathrm{bp}$ ladder (Ggibco BRL), were used for electrophoresis. Bands were visulised under UV light on a transilluminator and photographed by image documentation system (Labortechnic, Germany).

\section{Preparation of the vaccines:}

\section{A. Ribosome vaccine}

The pure culture of E.coli isolates were sub-cultured on nutrient broth for 16 hour at $37{ }^{\circ} \mathrm{C}$ and harvested by centrifugation ( $4000 \mathrm{xg}$ for 10 minute at $4{ }^{\circ} \mathrm{C}$ ). The pellet was re-suspended in phosphate-buffered saline (PBS), washed three times and re-suspended in $100 \mathrm{ml} \mathrm{PBS}$ at a concentration of $2 \times 10^{9} \mathrm{CFU} / \mathrm{ml}$.
Suspended E.coli were broken by ultrasonication at $18 \mathrm{kc}$ force for a period of 25 minutes, then centrifuged at $27000 \times \mathrm{g}$ for 10 minutes at $4^{\circ} \mathrm{C}$, the supernatant fluid were separated and re-centrifuged at $45000 \mathrm{x} \mathrm{g}$ for 30 minutes to precipitate the wreckage of the remaining cells.

Supernatant fluid (4/5) were separated carefully, recentrifuged at 105,000 x g for 3 hours to get the parts containing ribosomes. Ribosomal vaccine $(20 \mathrm{mg} / \mathrm{ml})$ was prepared according to (Venneman and Bigley, 1969), then the total protein was determined by Biuret method and used for immunization.

\section{B. Lipopolysaccharide vaccine}

Lipopolysaccharide vaccine was prepared by using hot phenol according to (Westphal and Jann, 1965). Fifteen liter of special media which was previously mentioned are cultured by E.coli and incubated at 37 ${ }^{\circ} \mathrm{C}$ for 3 days then harvested by PBS and centrifuged at $5000 \times \mathrm{g}$ for 30 minutes. The supernatant was discarded and precipitates were re-suspended in PBS using $88 \mathrm{ml}$ distilled water, heated to $68{ }^{\circ} \mathrm{C}$ and mixed well. Eighty eight $\mathrm{ml}$ of phenol was added and heated to $68 \mathrm{C}^{\circ}$ and mixed well using magnatic sterror at maximum speed for 10 minutes, and after concerning the efficiency of mixing put the flask containing the mixture in water bath at $68{ }^{\circ} \mathrm{C}$ for 30 minutes. The flask was then placed directly in the ice bath at $10{ }^{\circ} \mathrm{C}$ for 10 minutes. Then the emulsion was formed and centrifuged at $5000 \times \mathrm{g}$ for 20 minutes, and it was noted that three phases was formed, the aqueous phase, the phenolic phase, and other phase represent proteins and other waste product (Figure 3- 
1). Then the aqueous phase gently sucking to sterile tube by pipette. The phenolic phase and protein phase are re-extracted by adding $88 \mathrm{ml}$ of distilled water heated to $65{ }^{\circ} \mathrm{C}$ and mix well, where the previous operation returned again.
Collection the water phase resulting from the processes of extraction and adding to it $1 \mathrm{mg} / \mathrm{ml}$ of DNase, RNase then incubate at $37{ }^{\circ} \mathrm{C}$ for 24 hours, and then held for the solution process of dialysis against distilled water for 4 days. Then the liquid is maintained collected.

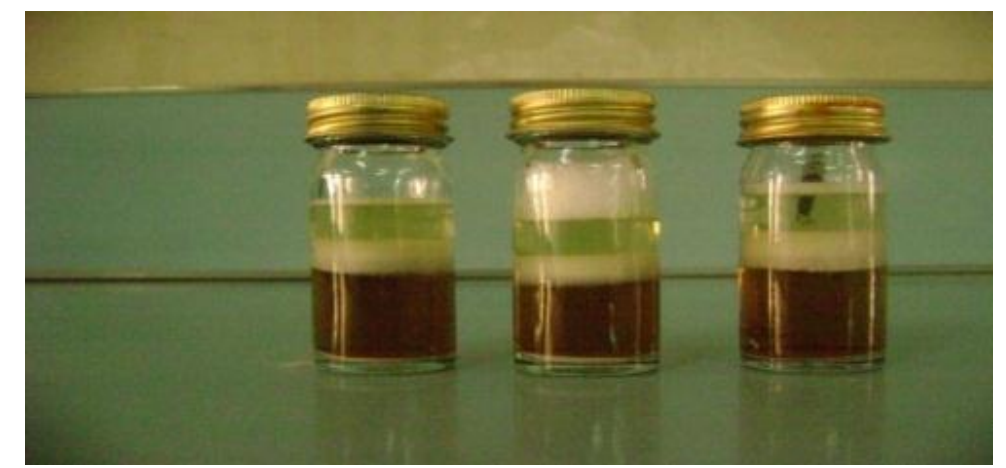

Figure 1: Showed 3 main phases. Aqueous phase, phenolic phase, and other phase represent proteins and other waste product.

\section{Experimental design:}

Seventy five (75) broiler one day old chicks were divided into 3 groups; Group 1 were injected with 0.5 $\mathrm{ml}$ of LPS antigen. Group 2 were injected with 0.5 $\mathrm{ml}$ of ribosome antigen at a concentration of $2 \times 10^{9}$ $\mathrm{CFU} / \mathrm{ml}$. Group 3 were injected with $0.5 \mathrm{ml}$ of physiological saline solution. At seven days of age groups, 1, 2, and 3 were vaccinated with the prepared vaccines subcutaneously. Blood samples were collected at 10 days post vaccination to determine the antibody titers by ELISA and PHA test.

At day $19^{\text {th }}$ of age challenging test $\left(1 \times 10^{8} \mathrm{CFU} / \mathrm{ml}\right.$ $\mathrm{S} / \mathrm{C}$ ) were conducted. Blood samples were collected at 10 days post challenging to determine the antibody titers by ELISA and PHA test.

\section{Passive Hemagglutination test (PHA)}

PHA test were carried out according to Herbert, (1987).

\section{A. Sheep RBCs}

Five $\mathrm{ml}$ of sheep blood was collected by sterile syringe, then mixed with $5 \mathrm{ml}$ of Alsevers solution, which may be kept at $4 \mathrm{C}^{\circ}$ for $24-72$ hours. Blood sample was centrifuged at $1500 \mathrm{rpm}$ for 10 minutes to discard Alsevers solution. Blood sample was washed three times with PBS $(\mathrm{pH}=7.2)$ and centrifugation at $1500 \mathrm{rpm} / 5$ minutes. RBCs were resuspended in PBS for final concentration of $2.5 \%$.

\section{B. Tanned RBCs}

Ten $\mathrm{ml}$ of $(2.5 \%)$ RBCs was mixed with equal volume of tannic acid solution (1:20000), incubated at $37 \mathrm{C}^{\circ}$ for 20 minutes and shaked gently every 5 minutes, then the mixtures was centrifuged at 2000 rpm for 10 minutes to remove tannic acid solution, then RBCs washed three times with PBS ( $\mathrm{pH}=7.2)$ and centrifugation at $1500 \mathrm{rpm}$ per 5 minutes.

\section{Sensitization of washed tanned RBCs}

Serial dilutions of particular antigen were prepared to sensitize washed tanned RBCs and to detect the optimal antigen concentration which gave appositive reaction with higher antibody dilution.

One $\mathrm{ml}$ of sonicated APEC antigen was mixed with one $\mathrm{ml}$ washed tanned RBCs then incubated at $37^{\circ} \mathrm{C}$ for 30 minutes, and gently shaked every 5 minutes, then the mixture was centrifuged at $2000 \mathrm{rpm}$ per10 minutes to remove the excessive antigens, finally the sensitized RBCs were washed with PBS ( $\mathrm{pH}=7.2$ ) and centrifuged at $1300 \mathrm{rpm}$ per 5 minutes three times.

\section{Serum inactivation}

The serum samples were incubated at $56{ }^{\circ} \mathrm{C}$ for 30 minutes in water bath to impair the complement activity.

\section{Procedure}

Add $50 \mu \mathrm{l}$ of normal rabbit serum to wells of microtiterplate (96 $\mathrm{U}$ shape wells), then added $50 \mu \mathrm{l}$ of serum sample to first well in raws, then made serial dilutions of serum by pipetting $50 \mu$ l of mixture and transferred to next wells until last well, from which $50 \mu \mathrm{l}$ was discarded, then to each well $50 \mu \mathrm{l}$ from sensitized tanned RBCs was added, and the plate covered with aluminum paper and incubated at room temperature for at least $2 \mathrm{hrs}$, after that, the reactions was read, reading was repeated after 18 hours $/ 4{ }^{\circ} \mathrm{C}$.

The positive results was appeared when RBCs agglutinate and form carpet shape. The negative reaction was appeared when RBCs precipitate at bottom as dot like without agglutination. 


\section{ELISA test:}

ELISA test was done according to (Leitner et al., 1990), the kit of ELISA including E.coli Ab Conjugate, Substrate A, Substrate B, Stop solution E.coli antibody Negative control and E.coli antibody positive control.

\section{Challenge test:-}

Ten fold dilutions from E.coli were prepared from 24 hours culture on peptone water to obtain $1 \mathrm{X} 10^{8}$ $\mathrm{CFU} / \mathrm{ml}$ to be used for experimental infection of chick according to (Sambrook et al., 1989).

\section{RESULT}

Escherichia coli/ vaccine strains were obtained from chickens died with colibacillosis (Fig.2), the results

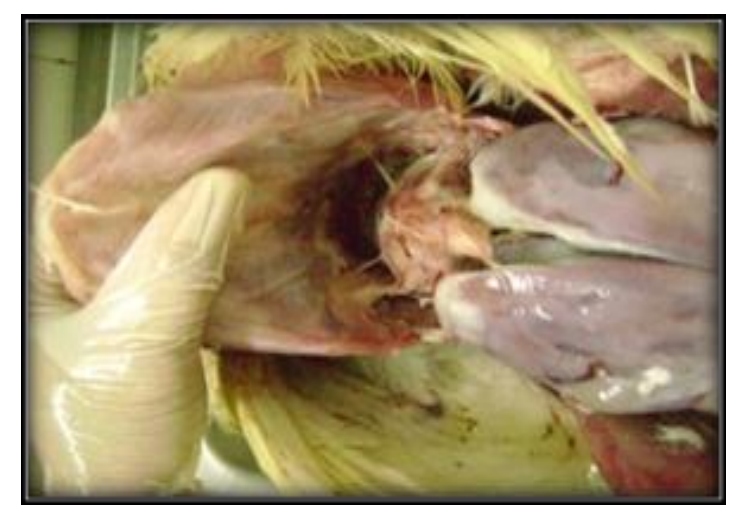

Figure 2: Shows typical perihepatitis in broiler chicks caused by avian colibacillosis of gross colony morphology on McConkey's agar was as a convex shape, dark pink color and, on EMB agar was as a characteristic of metallic green sheen, and then the E.coli isolates were confirmed by using API E 20 test see (Fig.3).

Instead of biochemical API 20E tests, PCR and its related method have been reported to identify $E$. coli. In this study, the isolated E. coli organisms from colibacillosis diseased birds were grown in nutrient broth, DNA was extracted and amplified by PCR using ECO-f and ECO-r primer targeting E. coli $16 \mathrm{~S}$ ribosomal DNA. On agarose gel electrophorsis, single band was visualized at molecular weight of 585 bp, (Fig. 4).

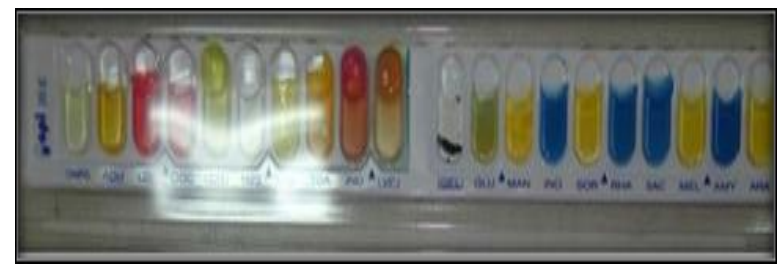

Figure 3: The results of biochemical tests in API 20E system by isolated strain of Escherichia coli.

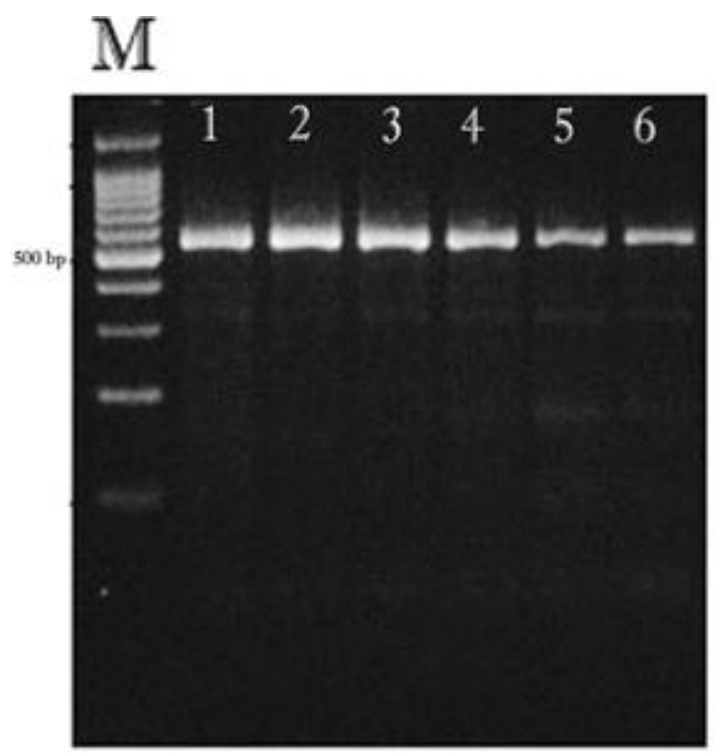

Figure 4: Agarose gel electrophorsis showing the PCR amplified products of E. coli 16S ribosomal DNA. Lanes M: DNA molecular weight marker (100 bp ladder marker with molecular weight range from 00 - 3000 bp); Lanes 1 to 6: positive with 585 base pair. 
Antibody titers to LPS, ribosome, and control vaccine were measured by using ELISA and PHA tests at $17^{\text {th }}$ and $29^{\text {th }}$ day of age, it was found that there were significant differences $(\mathrm{P}<0.05)$ among all groups as showing in the Table (1), after vaccination and challenging. Immune response of vaccination measured by ELISA showed a significant increase $(\mathrm{P}<0.05)$ in ELISA titer of all groups as compared with the control group. The vaccinated group with ribosomal vaccine showed a significant increase $(\mathrm{P}<0.05)$ more than that of LPS vaccine, while immune response measured by (PHA) showed a significant increase in immune response $(\mathrm{P}<0.05)$ in all vaccinated groups as compared with the control one as show in Table (2). The group vaccinated with ribosome vaccine showed a significant increase $(\mathrm{P}<$ $0.05)$ more than that of LPS group.

Table 1: Antibody titers to LPS and ribosome, control vaccine by using ELISA at at $17^{\text {th }}$ and $29^{\text {th }}$ day of age.

\begin{tabular}{ccc}
\hline Groups & Antibody titers $\left(\right.$ Mean \pm SE) at $17^{\text {th }}$ days & Antibody titers $\left(\right.$ Mean \pm SE) at 29 ${ }^{\text {th }}$ days \\
\hline LPS & $1.275 \pm 0.095$ & $1.849 \pm 0.038$ \\
& $\mathrm{~B}$ & $\mathrm{~B}$ \\
\hline Ribosome & $1.592 \pm 0.046$ & $2.048 \pm 0.048$ \\
& $\mathrm{~A}$ & $\mathrm{~A}$ \\
\hline Control vaccine & $0.046 \pm 0.009$ & $0.985 \pm 0.010$ \\
& $\mathrm{C}$ & $\mathrm{C}$ \\
\hline
\end{tabular}

The different capital letters refer to significant difference $(\mathrm{P}<0.05)$ among groups Means $\pm S E(n=8)$.

Table 2: Antibody titers of chickens after immunization with LPS and ribosome vaccines at $17^{\text {th }}$ and $29^{\text {th }}$ day of age.

\begin{tabular}{ccc}
\hline Groups & Antibody titers $($ Mean \pm SE) at 17 th days & Antibody titers (Mean \pm SE) at 29th days \\
\hline LPS & $192 \pm 24.189$ & $1344 \pm 215.003$ \\
& $\mathrm{~B}$ & $\mathrm{~B}$ \\
\hline Ribosome & $272 \pm 56.406$ & $1792 \pm 374.746$ \\
& $\mathrm{AB}$ & $\mathrm{A}$ \\
\hline Control & $3.75 \pm 0.700$ & $256 \pm 112.813$ \\
& $\mathrm{D}$ & $\mathrm{C}$ \\
\hline
\end{tabular}

The different capital letters refer to significant difference $(\mathrm{P}<0.05)$ among groups Means \pm SE $(\mathrm{n}=8)$.

The number of mortality in LPS vaccinated, ribosome vaccinated and control groups were two, one and six chickens respectively as shown in Table (3).

Table 3: Number of mortality of broiler chickens vaccinated with different E.coli vaccines after challenging.

\begin{tabular}{cccc}
\hline Group & LPS & Ribosome & Control \\
\hline Mortality & $2 / 25$ & $1 / 25$ & $6 / 25$ \\
\hline
\end{tabular}

\section{DISCUSSION}

Escherichia coli isolates were collected from chickens with colibacillosis in broiler farms around Sulaimania Province, The clinical manifestations were observed in the affected birds with colibacillosis in addition to, inflammatory changes such as pericarditis, perihepatitis and air sacculitis were seen in the autopsied birds as show in (Fig.1), (Omer et al., 2008).

The isolated E.coli were identified by using different biochemical tests, and it was found that these isolates were gram negative bacilli, it's appearance on Macconkey's agar was as a convex shape, dark pink color colonies by fermenting lactose sugar, while its appearance on EMB agar was metallic green sheen colonies, and these isolates were confirmed by using API E20 test (Fig. 3), and by using specific base pair primer for E. coli $16 \mathrm{~S}$ ribosomal DNA identification by PCR (Fig.4), this result was similar to other authors (Amith-Romach et al., 2004).

Antibody titers to LPS vaccinated, ribosome vaccinated, and control are measured by using ELISA tests at $17^{\text {th }}$ and $29^{\text {th }}$ day of age, it was found 
that there were significant differences $(\mathrm{P}<0.05)$ among all groups as showed in the Table (1), after vaccination and challenging. Immune response of vaccination measured by ELISA showed a significant increase $(\mathrm{P}<0.05)$ in ELISA titer of all groups as compared with the control group. The group vaccinated with ribosomal vaccine showed a significant increase $(\mathrm{P}<0.05)$ more than that of LPS vaccine. These results are agreed with (Panigaraphy et al., 1984), who mentioned that vaccinated chickens were protected against colibacillosis infection as compared to those unvaccinated. Gyimah et al. (1985), noted that vaccinated chicks showed high antibody titers, suffered low morbidity and mortality، mild gross lesions significantly lower than unvaccinated one.

Stimulation of Toll-like receptor - 4 (TLR-4) by lipopolysaccharide (LPS) results in the expression of the pro-inflammatory cytokine IL-1 3 . Toll-like receptor 4 detects the presence of pathogen and this result coincides with (Akashi et al., 2001), who stimulates bacterial killing mechanisms, and induces pro-inflammatory cytokines (Kogut et al., 2005). LPS induce an immune response that mimics the immune response to a bacterial infection, LPS increased the release of cytokines and induced an inflammatory response, which is followed by the production of antibodies (Poxton, 1995; Leshchinsky and Klasing, 2001).

Lipopolysaccharide showed direct activation of Blymphocytes in vitro, and produced antibodies of diverse specificities, mainly of the IgM type within a short of time period (Andersson et al., 1978).

The ribosomal vaccine, showed to be recognized by the immune system of the host with high frequency and this result agrees with (Requena et al., 2000). Ribosomal vaccine leading to the direct stimulation of B- lymphocytes and T-cell involvement through the release of cytokines which could modulate B-cell differentiation and immunoglobulin secretion. Uptake and presentation of these ribosomal protein antigens lead to strong immune responses against these antigens. The ribosomal vaccine leading to the immunoregulatory processes by their action on the $\mathrm{B}$ cells, $\mathrm{T}$ cells and cytokines secretion (Sven and Hofstad, 1990).

Passive heamagglutination test is considered a routine method for the quantification of antibody titers (Stavitsky, 1954). Immune response measured by (PHA) showed a significant increase in immune response $(\mathrm{P}<0.05)$ in all vaccinated groups as compared with the control group. The group vaccinated with ribosome vaccine showed a significant increase $(\mathrm{P}<0.05)$ more than that of LPS group.

It is clear that there was a great correlation between the results of ELISA and PHA tests. These results agree with (Leitner et al., 1990) and (Rosenberger et al., 1985), who found that there was higher correlation between ELISA and PHA titer, and the titer in both tests were parallel.

Melamed et al. (1991) recorded that the degree of protection conferred by the vaccine was positively correlated with the antibody titer against colliabicllosis.

Chicks from the control non vaccinated showed poor immune response than that from vaccinated when challenged by E. coli. These results are agreed with (Panigaraphy et al., 1984), who mentioned that vaccinated chickens were protected against active respiratory infection showed more immune response as compared with those unvaccinated.

Group vaccinated with Ribosome produce good immunity against challenge and this is due to ribosome elicits both humeral and cell mediated immunity and this result was agreement with that of (Youmans and Youmans, 1970; Venneman, 1972), whom noticed that serum antibodies against ribosomes were apparent 7 days after injection of the ribosomal vaccine as measured by PHA test. Whereas (Jonson, 1972; Swendsen and Johnson, 1976) demonstrated that ribosomal protein acts as the principle immunogen.

LPS vaccine showed high antibody titeration measured by PHA test and this result was agreement with (Chen et al., 1999), who found that vaccination with LPS were giving good protection and using the PHA test was much more sensitive in detecting E.coli antibodies. Also (Yaguchi et al., 2009) mentioned that the all chickens vaccinated with the LPS produced anti-lipopolysaccharide antibodies of the IgG sub-class in their sera, rise in antibodies in the serum of chickens administered the LPS vaccine.

The difference in the mortality between groups may be due to the degree of protection conferred by the vaccine was positively correlated with the antibody titer against collibacillosis (Melamed et al., 1991).

Mortality caused by APEC infection may be due to that after invading the bloodstream APEC causes a septicemia resulting in massive lesions in multiple internal organs and in sudden death of the birds (Ewers et al., 2003).

The ability of the bacteria to acquire iron and the resistance to the bactericidal effects of serum, predominantly conferred by the increased serum survival (ISS)-protein, enables APEC to multiply quickly in their hosts. increased serum survival (ISS) is regarded a specific genetic marker for avian pathogenic E. coli strains (Stordeur et al., 2004). 


\section{REFERENCE}

Akashi, S.; Nagai, Y.; Ogata, H.; Oikawa, M.; Fukase, K.; Kusumoto, S.; Kawasaki, K.; Nishijama, M.; Hayashi, S.; Kimoto, M. and Miyake, K. (2001): Human MD-2 confers on mouse toll-like receptor 4 species-specific lipopolysaccharide recognition. International Immunology. 13: 1595-1599.

Amit-Romach E., Sklan, D. and Uni, Z. (2004): Microflora Ecology of the Chicken Intestine Using 16S Ribosomal DNA Primers. Poultry Science, 83: 1093-1098.

Andersson, J.; Coutinho, A.; Melchers, F. (1978): Stimulation of murine B lymphocytes to $\mathrm{IgG}$ synthesis and secretion by the mitogens lipopolysaccharide and lipoprotein and its inhibition by anti-immunoglobulin antibodies. Europian Journal Immunology, 8: 336-343.

Arp, L.H. (1980): Consequences of active or passive immunization of turkeys against Escherichia coli O78. Avian Diseases, 24, 808-815.

Ask, B.; van der Waaij, E.H.; Stegeman, J.A. and van Arendonk, J.A.M. (2006): Genetic variation among broiler genotypes in susceptibility to colibacillosis. Poultry Science, 85: 415-421.

Barnes, H.J.; Vaillancourt, J.P. and Gross, W.B. (2003): Colibacillosis. In Diseases of Poultry. $11^{\text {th }}$.

Ed. Barnes, H.J.; Fadly, A.M.; Glisson, J.R.; McDougald, L.R.; Swayne, D.E. and Saif, Y. M. ed. Iowa State University Press, Ames. 631-656.

Candrian, U.; Furrer, B.; Hofelein, C.; Meyer, R.; Jermini, M. and Luthy, J. (1991): Detection of Escherichia coli and identification of enterotoxigenic strains by primer-directed enzymatic amplification of specific DNA sequences. International Journal of Food Microbiology, 12: 339-351.

Chen S.L.; Qiu Z.F.; and Lin, W.Q. (1999): The immunogenicity of ultrasonicated vaccine of chicken pathogenic E. coli (O78) against colibacillosis. Chinese Journal of South China Agricultural University. 20(1): 37-40.

Deb, J.R. and Harry, E.G. (1976): Laboratory trials with inactivatedvaccines against Escherichia coli 078: K80 infection in fowls. Research of Veterinary Science. 20: 131-138.

Ewers, C.; Janseen, T. and Wieler, L.H. (2003): Avian pathogenic E.coli (APEC). Berl. Munch. Tierarztl. Wochenschr. 116: 381-395.

Gross, W.B. (1990): Factors affecting the development of respiratory disease complex in chickens. Avian Diseases. 34: 607- 610.

Gymiah, J.E.; Panigraphy, B.; Halle, P. and William, J.B. (1985): Immunogicity of an oil emulsified Escherichia coli bacterin against heterologous challenge. Avian Disease. 29 (2): 540-545.
Herbert, W.J. (1978): Passive heamagglutination with special references with the tanned cell technique, Ch.20. In: Weir, D.M.; Handbook of Experimental Immunology. $3^{\text {rd }} \mathrm{Ed}$, Cellular Immunology. Blackwell Scientific Publ. 11(20): 1-20.

Johnson, W. (1972): Ribosomal vaccines. Immunogenicity of ribosomal fractions isolated from Salmonella typhimurium and Yersinia pestis. Infectious Immunology. 5: 947-952.

Kariyawasam, S.; Wilkie, B.N.; Hunter, D.B. and Gyles, C.L. (2002): Systemic and mucosal antibody responses to selected cell surface antigens of avian pathogenic Escherichia coli in experimentally infected chickens. Avian Diseases. 46: 668-678.

Kogut, M.H.; Iqbal, M.; He, H.; Philbin, V.; Kaiser, P. and Smith, A. (2005): Expression and function of toll-like receptors in chicken heterophils. Development Comp. Immunology. 29: 791-807.

Leitner, G.; Melamed, D.; Drabkin, N. and Heller, E.D. (1990): An enzyme -linked immunosorbent assay for Detection of antibodies against Escherichia coli: Association between indirect hemagglutination tests and survival." Avian Disease, 34(1): 58-62.

Leshchincky, T.V. and Klasing, K.C. (2001): Divergence of the inflammatory response in two types of chickens. Developement Comp. Immunology, 25: 629-638.

Lynne, A.M.; Kariyawasam, S.; Wannemuehler, Y.; Johnson, T.J.; Johnson, S.J.; Sinha, A.S.; Lynne, D.K.; Moon, H.W.; Jordan, D.M.; Logue, C.M.; Foley, S.L. and Nolan, L.K. (2012): Recombinant Iss as a potential vaccine for avian colibacillosis. Avian Diseases. 56(1): 192-9.

McPeake, S.J.; Smyth, J.A. and Ball, H.J. (2005): Characterisation of avian pathogenic Escherichia coli (APEC) associated with colisepticaemia compared to faecal isolates from healthy birds. Veterinary Microbiology. 110: 245-253.

Melamed, D.; Leitner, G. and Heller, A. (1991): A vaccine against avian colibacillosis based on ultrasonic inactivation of Escherichia coli. Avian Diseases. 35: 17-22.

Moulin-Schouleur, M.; Reperant, M. and Laurent, S. (2007): Extra intestinal pathogenic Escherichia coli strains of avian and human origin: link between phylogenetic relationships and common virulence patterns. Journal Clinical Microbiology, 45: 33663376. doi:10.1128/ JCM.00037-07.

Nagano, T.; Kitahara, R. and Nagai, S. (2012): An attenuated mutant of avian pathogenic Escherichia coli serovar O78: a possible live 
vaccine strain for prevention of avian colibacillosis. Microbiology Immunology. 56(9): 605-12.

Omer, M.M.; Khalda, A.; Abusalab, S.M.; Gumaa, M.M.; Mulla, S.A. and Ahmed, A.M. (2008). An outbreak of gumboro disease associated with colibacillosis among broiler and layer chicks in Kassala State, Eastern Sudan. RJPS., 2: 27-28.

Panigrahy, B.; Gyimah, J.E.; Hall, C.F. and Williams, J.D. (1984): Immunogenic potency of an oil-emulsified Escherichia coli Bacterin. Avian Diseases. 28: 475-481.

Poxton I. (1995): Antibodies to lipopolysaccharide. Journal of Immunology Methods. 186: 1-15.

Requena, J.M.; Alonso, C. and Soto, M. (2000): Evolutionary conserved proteins as proeminent immunogens during Leishmania infections. Parasitology, 16: 246-250.

Rosenberger, J.K.; Fries, P.A. and Cloud, S.S. (1985): In Vitro and In Vivo Characterization of Avian Escherichia coli. III. Immunization. Avian Diseases, 29 (4):19717-1303.

Sambrook, J.; Fritsch, E.F. and Maniatis, T. (1989): Molecular coloning. A laboratory manual. New York. Cold spring Harbor. Laboratory Press.

Stavitsky, A.B. (1954): Micro methods for the study of proteins and antibodies. I. Procedure and general applications hemagglutination and heamagglutination inhibition reactions with tannic acid and protein treated red blood cells. Journal of Immunology, 72: 360-367.

Stordeur, P.; Bree, A.; Mainil, J. and MoulinSchouleur, M. (2004): Pathogenicity of papnegative avian Escherichia coli isolated from septicaemic lesions. Microbes and Infection. 6: 637-645.

Sven, K. and Hofstad, T. (1990): Blastogenesis and polyclonal immunoglobulin synthesis in murine spleen cells stimulated with lipopolysaccharide, lipid A and acid degraded.
FEMS Microbiology and Immunology. 2: 29-32.

Swendsen, C.L. and Johnson, W. (1976): Humoral immunity to Streptococcus pneumoniae induced by a pneumococcal ribosomal protein fraction. Infection and Immunity. 14: 345-354.

Vandekerchove, D.; de Herdt, P.; Laevens, H. and Pasmans, F. (2004): Colibacillosis in caged layer hens: characteristics of the disease and the aetiological agent. Avian Patholology. 33(2): 117-125.

Venneman, M.R. (1972): Purification of immunogenically active ribonucleic acid preparations of Salmonella typhimurium: molecular sieve and anion-exchange chromatography. Infection and Immunity. 5: 269-282.

Venneman, M.R. and Bigley, N.J. (1969): Isolation and partial characterization of an immunogenic moiety obtained from Salmonella typhimurium. Journal of bacterialogy. 100 (1): 140.

Westphal, O. and Jann, K. (1965): Bacterial LPS extraction with phenol water and further application of the procedure, p.83-91.In R.L. whistter (ed), Methods in carbohydrate chemistry. Academic Press, Inc., New York.V.5.

Yaguchi, K.; Ohgitani, T.; Noro, T.; Kaneshige, T. and Shimizu, Y. (2009): Vaccination of chickens with liposomal inactivated avian pathogenic Escherichia coli (APEC) vaccine by eye drop or coarse spray administration. Avian Diseases. 53(2): 245-9.

Yang, H. (2003): Animal immunology. 2nd ed. Beijing: China Agriculture University Press.

Youmans, A.S. and Yonumans, G.P. (1970): Immunogenic mycobacterial ribosomal and ribonucleic acid preperations: chemical and physical properties. Infectious Immunology, 2: 659-668.

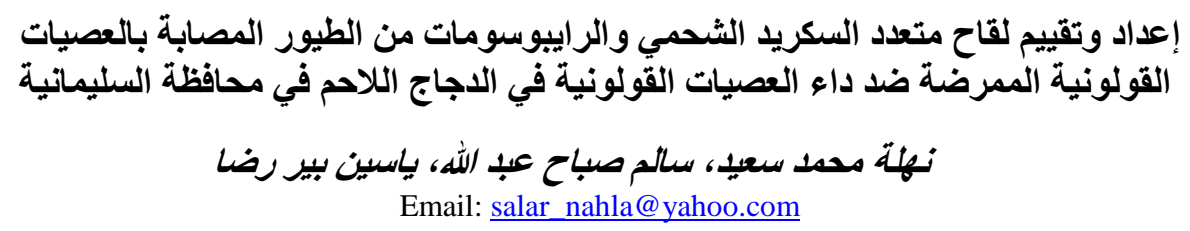

وقد أجريت هذه الدر اسة لتقييم فعالية لقاح متعدد السكريد الثحمي ولقاح الريبوسوم على العصيات القولونية المعزولة من حقول فروج

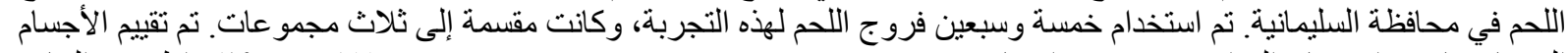

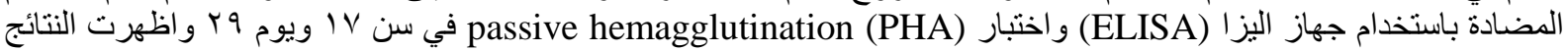

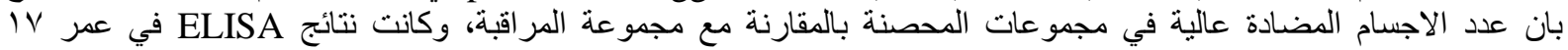
للمجموعة الملقحة ب متعدد السكريد الثحمي

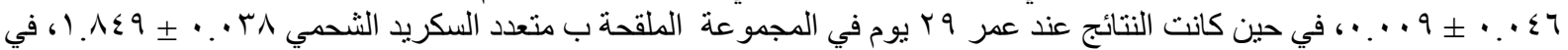

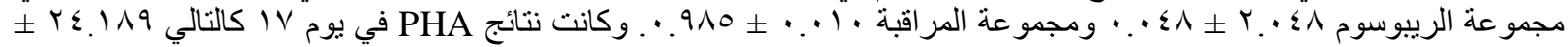

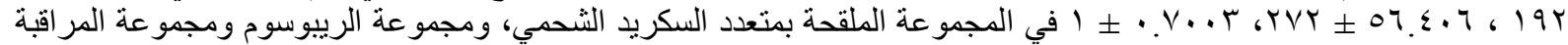

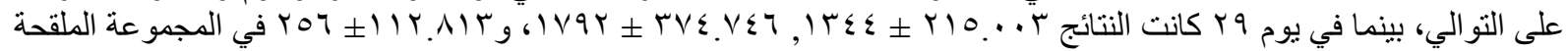

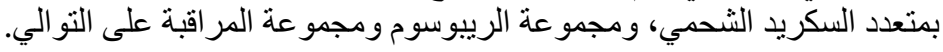

